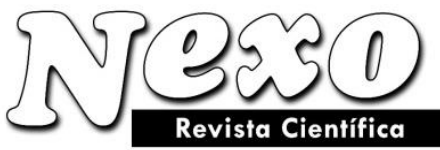

ISSN-E 1995-9516

Universidad Nacional de Ingeniería COPYRIGHT @ (UNI). TODOS LOS DERECHOS RESERVADOS

http://revistas.uni.edu.ni/index.php/Nexo

https://doi.org/10.5377/nexo.v34i04.12684

\title{
Simulation and risk management of financial activities in the digital economy era
}

\section{Simulación y gestión de riesgos de actividades financieras en la era de la economía dogital}

\author{
Mikhail Samuilovich Gasparian*, Irina Anatolievna Kiseleva, Valery Aleksandrovich Titov, \\ Leonid Anatolyevich Olenev
}

Plekhanov Russian University of Economics. Moscow, Russian Federation.

*Corresponding author E-mail: gasparian.m.s@ mail.ru

(recibido/received: 14-mayo-2021; aceptado/accepted: 30-julio-2021)

\begin{abstract}
The present article attempts to study the role of financial risk management in the digital economy era. The main purpose of the article is to identify the main patterns that determine the features of risk assessment in business as the main element contributing to the achievement of economic security of the organization, as well as to carry out a comparative analysis of risk assessment and risk management methods in the context of digitalization. The contemporary economic analysis employs various risk management methods. Digitalization also creates new risks, most of which are related to cybercrime and fraud on the Internet. The most effective ways to reduce risk in the context of instability of the economic and political situation in Russia are the scenarios method and the method of analyzing hierarchies, as well as diversification, i.e. the distribution of risks among several business participants. The article discusses various types of economic risks, risk analysis, and assessment methods, as well as risk neutralizing strategies.
\end{abstract}

Keywords: Model; Innovation; Risk; Risk management; Digitalization; Financial activity.

\section{RESUMEN}

El presente artículo intenta estudiar el papel de la gestión del riesgo financiero en la era de la economía digital. El objetivo principal del artículo es identificar los principales patrones que determinan las características de la evaluación de riesgos en los negocios como el elemento principal que contribuye al logro de la seguridad económica de la organización, así como realizar un análisis comparativo de evaluación de riesgos y riesgos. métodos de gestión en el contexto de la digitalización. El análisis económico contemporáneo emplea varios métodos de gestión de riesgos. La digitalización también crea nuevos riesgos, la mayoría de los cuales están relacionados con el ciberdelito y el fraude en Internet. Las formas más efectivas de reducir el riesgo en el contexto de inestabilidad de la situación económica y política en Rusia son el método de escenarios y el método de análisis de jerarquías, así como la diversificación, es decir, la distribución de riesgos entre varios participantes comerciales. El artículo 
analiza varios tipos de riesgos económicos, análisis de riesgos y métodos de evaluación, así como estrategias de neutralización de riesgos.

Palabras claves: Modelo; Innovación; Riesgo; Gestión de riesgos; Digitalización; Actividad financiera.

\section{INTRODUCTION}

The existing need to ensure continued growth in the efficiency of companies' performance during the period of active digitalization of financial activities creates the need for timely detection, identification, minimization, and reduction of financial risks to ensure their manageability at all organization's levels. Digital technologies, tools, and new methods of data analysis are gradually being implemented into all types of economic relations. The ambiguity of the digitalization process lies in the fact that, along with the convenience and benefits, it brings new risks to the business that entails the possibility of adverse consequences for the company which may lose its income or assets. It is impossible to completely avoid the risks that appear in the course of the digitalization of the economy since digitization penetrates more actively and fully into various spheres of life of society and business over time.

The digital economy can be interpreted as an economic activity in which the key role is played by the data presented in electronic and digital form. Such a definition also implies the inclusion the data processing and the application of research results into the concept of the digital economy that makes it possible to improve the quality and effectiveness of various types of technologies, equipment, production, sales, services provision, and data storage in comparison with traditional business patterns. In 2017, a document entitled "Digital Economy of the Russian Federation" was created and approved (Government of the Russian Federation, 2017). This is a program of the Government of the Russian Federation, whose essence is to create an ecosystem of the digital economy in Russia, in which the information presented in digital form is the main factor of production in each sector of the economic and financial activity.

Innovations in the field of technology have a great impact on the development trends of the financial system. In recent years, the largest percentage of global innovation has been associated in one way or another with the development of digital technologies. An increase in new applications being developed from year to year simplifies the possibility of making contactless, instant, mobile payments, investment consulting, data management and information storage, asset management, and informing various participants in financial and economic relations about the status of their assets (Makarenko, 2020; Tereshchenko, 2019; Filippova, 2019; Cheredanova, 2018; Bezuglaya, 2013; Kleiner, 2014).

Digitalization affects the company's financial risk management in different ways. On the one hand, innovative digital technologies significantly simplify processes, develop tools and methods for detecting and preventing the occurrence of financial risks, but on the other hand, they also provoke the emergence of new risks that are particularly dangerous in the commercial sphere due to possibilities of direct financial losses.

\section{METHODS}

Data transparency in the digital economy era makes it possible to search for and find reliable information about the probability of risk occurrence and its possible consequences, which affects the efficiency of response and the ability to predict risks. Poor quality and incomplete information that gets into the use of employees of the organization increases the subjectivity of the data obtained at the output of their analysis, and reduces the competence of risk management, reducing the degree of its effectiveness. There is a huge variety of analytical platforms that quickly solve the problems of collecting and visualizing large amounts of information. The list of these platforms includes state information systems that are used by financial 
enterprises and allow companies to check the information provided by customers, as well as the solvency of their counterparties (Gomola, Kirillov and Zhannin, 2019; Tereshchenko, 2019; Gubanov, 2014).

Transparency also affected the aspect of financial transactions, which is expressed in state regulation through the imposition of accounting obligations and centralized clearing.

The spread of open data has enabled the practical application of large amounts of information obtained about customers, which has had a major impact on the development of tools for storing and analyzing large amounts of information (big data). To be able to manage such a large-scale information flow, the appropriate powerful computing facilities are needed. Among them, the most popular are cloud technologies, which, by providing a large information system, make it possible to use the advantages in terms of response and speed, freeing up resources for implementing other business functions.

Another advantage of digitalization is a significant reduction in the degree of influence of the human factor on the results of risk analyses. The mathematical and statistical analysis of the possibility of risk occurrence and the extent of caused damage, carried out by robots and artificial intelligence, is carried out using computer technologies that have significantly greater accuracy of the results obtained. Currently, a huge list of programs has been designed for use by specialists of various departments of the company, such as Microsoft Excel, which contains an array of formulas that simplify the calculation processes, and tools for visualizing the resulting data, as well as Microsoft Access, etc.

\section{RESULTS}

First of all, the digitalization of financial activities poses a threat to central banks that carry out their activities to ensure safe financial transactions. With the development of the financial services market and the emergence of a large number of new participants in this segment, as well as payment methods, new sources of risks have emerged associated with making payments.

The risk of data privacy violations is closely related to financial risks. It is associated with fraud in the field of information technology and data theft to blackmail its owners, first of all, various companies. This risk is exacerbated by the growing number of malicious software and the range of their distribution channels. When penetrating a computer system, these programs block files and encrypt them to obtaining further a ransom for the return of information. After paying the ransom, a certain percentage of defrauded firms do not get their data (Foss, 2005; Kiseleva and Simonovich, 2014; Avilkina, 2020).

Another risk is the loss of financial benefits of enterprises. It is associated with the opportunity for companies to receive investments through crowdfunding (a tool for accumulating investments based on Internet platforms). This is especially important for innovative businesses, which are constantly having to adapt to the emergence of new financial instruments generated by digitalization, and helping to find additional sources of financing.

To a greater extent, cyber risks are exposed to technology companies that have the Internet-based business model. These companies should develop an IT security policy as fully as possible, based on the best practices that exist in the market. In addition, this risk management requires fruitful cooperation with the competent authorities at both the state and the international level.

Digitalization of financial activities also contributes to the strengthening of two standard risks for the financial system, namely, liquidity risk and credit risk. Liquidity risk is associated with the evolution of enterprises engaged in high-frequency trading. Credit risk may be associated with the development of crowdfunding. The main problem consists in the amount of funds raised in this way. At the moment, these are small financial flows, but in the future, the volumes may grow due to the popularization of 
crowdfunding platforms. Regulatory agencies will have to ensure that the development of these financing channels does not pose a threat to financial stability, as well as to the legal security of individual investors. For example, future risks may lie in the lack of guarantees of the security and sustainability of crowdfunding platforms through which financial payments are transferred. Consequently, platforms will be required to provide Internet users with all the information necessary to evaluate investments.

The risk of not being able to receive additional investment arises for those enterprises that are unable to reorient their activities in the era of the digital economy. Over time, companies that miss out on their financing opportunities due to their commitment to traditional sectors of the economy may find themselves out of the game (Bardovsky, 2019; Zhilkina, 2020; Vakhitov, 2018; Filippova, 2019; Cheredanova, 2018).

\section{DISCUSSION}

One of the studies of $\mathrm{PwC}$ company, which provides audit, consulting, legal, and risk analysis services to enterprises in various economic sectors, was devoted to identifying the six most important characteristics for effective risk management in the era of digitalization of the economy. In this study, the employees of the organizations were divided into three groups: Innovators who promote progressive digital solutions and actively participate in the modernization of the company's systems, Followers, and Observers. The above six characteristics should be inherent to Innovators.

1. Application of the state-of-the-art technologies (establishing a reasonable balance of competencies for working with them).

At least 30\% of Innovators use the technological solutions of the Internet of Things when assessing risks and responding to them in the course of solving key tasks. For example, in the course of solving routine tasks, such as data extraction, they use robotics, while for more complex ones, such as complex database testing and monitoring of control tools, they turn to artificial intelligence. Automation of these processes allows freeing up employee resources and concentrating them on those tasks that from the company's standpoint will ensure greater efficiency.

Creative approach to new methods of solving risk-related problems. The top manager of FedEx developed a bot for compiling reports on various financial and economic indicators and performing quarterly quality assessments.

Automation of the key risk control function, including the risk of information privacy violations. In some companies, artificial intelligence allows analyzing the degree of data availability. For example, in Taylor Scott \& White Health, artificial intelligence analyzes the browsing history of medical records. This simplifies and reduces the work of employees, as the artificial intelligence provider regularly updates the used software.

Supporting digitalization for rapid development. Since many companies' activities cover several different industry sectors and areas rather than just one, automating several risk-related tasks with risk assessment helps enterprises move forward faster by implementing digital transformation. The digitalization scale and speed help when working with big data. Robotization, in particular, of the audit of certain areas, simplifies some processes and helps to find resources for organizing internal audits.

2. Full involvement in the company's digitalization plan.

The lack of specific goals eliminates the opportunity for the company to move forward. Innovators formulate and arrive at the planned results, define specific performance indicators in their digital 
innovation programs, which they adjust to the main strategies of their enterprises. Already at the design stage, Innovators make strategic recommendations, conduct research, and launch control tools that enable digital transformation according to planned and budget indicators. In most cases, they take part in digital initiatives, providing support for the implementation of digital transformation management standards at the enterprise. This support also includes the distribution of roles and functions (Morrow, Sirmon, Hitt and Holcomb, 2007; Domashchenko and Finogenova, 2010; PWC, 2019).

\section{Professional development and recruitment of professionals to match the company's development rate.}

In the context of modern economic development, the requirements for risk management managers are constantly changing. It is not uncommon to find a combination of certain managerial qualifications including experience in working with artificial intelligence. Therefore, to solve the problems of developing analytical models, meeting the need for technical skills, and developing programs for robotizing business processes, Innovators use the services of shared service centers.

Systematic evolution of competencies to improve the skills of working with artificial intelligence. The $\mathrm{PwC}$ company has created an in-house training strategy, which involves ranking the company's employees on three levels - specialists, developers, and users - based on their skills in artificial intelligence technologies. If the described strategy is applied to the risk management process, it turns out that all the staff will probably need some analytical skills, while a small group will be made up of professionals in the field of modeling and working with large amounts of information (Chereshkin, 2014; Kosov et al., 2016; Nesterenko, 2018).

Development of future-focused qualifications. Top Manager of Microsoft Corporation described the list of competencies that will be needed in the foreseeable future: "Tomorrow, we will need skills, more related to analyzing results and identifying priority solutions based on indicators and the importance. This is why auditors will need to better understand the implications of using technology. They don't need to know how to write computer code. But they need to understand what exactly is contained in this code, how solutions are embedded in automated processes, and how one can check the correctness of the codes and confirm them".

\section{Facilitating the company's real-time risk response.}

Top managers who contribute to the implementation of digital initiatives have the goal of obtaining more analytical information in real-time to quickly make qualitatively informed decisions. Innovators were the first who began to use tools for working with data and implementing digital solutions. Solutions, such as dashboards, provide an opportunity to prioritize using estimates based on the probability of risk occurrence, its consequences, and scale, as well as the time required to achieve the desired result. Among other things, innovators prioritize risks by resorting to the assistance of artificial intelligence. Detecting, monitoring, and testing a variety of risks in real-time can be performed using data lakes ${ }^{1}$. The employment of data lakes by risk managers in combination with artificial intelligence can become the strongest tool for detailed analysis of risks and operational data. Data lakes also allow managing information, because security tools can be easily embedded in any data sector. Accessible and authentic data is of great importance for digitalization. Firms provide themselves with a competitive advantage, striving to guarantee the maximum quality of information and its reliable storage, and, on the contrary, ignoring these aspects can weaken the competitive advantage of the company. Risk management functions that were not previously actively involved in information management should now be included in this process (Shapkin and Shapkin, 2013; Porter, 2005; PWC, 2019; Artemov and Ket'ko, 2021). The quality of the analysis

\footnotetext{
${ }^{1}$ A data lake is a centralized repository that allows storing all structured and unstructured data at any scale.
} 
carried out based on new technological processes directly depends on the initial data, since unreliable information can lead the management to incorrect decision-making.

5. Active involvement of managing executives in the implementation of major digital initiatives.

Innovators constantly communicate with stakeholders about the risks coming to the top during the implementation of innovations. They work closely with key digitalization teams to develop risk management strategies, are present when top-level managers discuss the risks associated with the implementation of digital solutions, and regularly inform the Board of Directors about risks using data visualization tools. These interactions allow Innovators to gain a clear vision of the main issues of the organization's functioning.

Exchange of visualized information. It is in the best interests of the Board of Directors to have as much information about the risks as possible. The functions upgraded from the standpoint of digital solutions can contribute to this. For example, the data on the list of audit objects of S\&P Global are located in the Tableau program. If the audit committee needs to obtain information about all high-risk companies, detailed information can be obtained in one click. Boards of Directors are also interested in obtaining data on the most important topics.

Key risk indicators. Key risk indicators enable the application of common terminology in the field of risk management. The absence of such a system also demonstrates the lack of uniform performance indicators. According to the results of the analysis conducted by $\mathrm{PwC}$ to assess the level of trust in digital technologies, only $27 \%$ of respondents are confident that their company's Board of Directors has all the necessary information about indicators related to cyber risk management and the risk associated with information privacy violations.

6. Partnership and unity of efforts towards forming a common view of risks.

The existence of various factors and indicators can create a distorted view of risks. Innovators try to act as a team, using common risk management concepts and indicators and trying to formulate a common idea of risks.

Using a single infrastructure to improve forecasting. The integration of infrastructure using data lakes allows the company to become the owner of advanced internal audit systems, and also helps firms to act ahead of the curve. A more detailed analysis of information, both internal and external, is a source of data used to assess the organization's risks, and draw up an action plan to manage them, which helps to strengthen the confidence of top management and the Board of Directors. The benefits obtained can be presented in various forms. The time has come to organize the coordinated teamwork of the risk management functions on all fronts of protection. Based on a single source of information on a single platform with a single set of technologies, risk management functions will be able to consolidate the most important information about risks for senior management, which can also be used by Boards of Directors, heads of departments, and other stakeholders to develop and make the most effective and flexible decisions.

\section{CONCLUSION}

Digitalization of the economy in terms of financial risk management is an ambiguous phenomenon. On the one hand, it creates many advantages contributing to saving labor and time resources, simplifying data analysis systems, storing and accumulating data, as well as ensuring the quality and accuracy of economic calculations. On the other hand, digitalization also creates new risks, most of which are related to cybercrime and fraud on the Internet. To reduce the likelihood of these risks, companies need to upgrade 
their security systems promptly and comply with the requirements for providing data to government agencies that control the transparency of financial transactions.

\section{ACKNOWLEDGEMENTS}

This research was performed in the framework of the state task in the field of scientific activity of the Ministry of Science and Higher Education of the Russian Federation, project "Development of the methodology and a software platform for the construction of digital twins, intellectual analysis and forecast of complex economic systems", grant no. FSSW-2020-0008.

\section{REFERENCES}

Artemov, V. E. and Ket'ko, N. M. (2021). Financial risk management in the context of digitalization. Retrieved from https://bstudy.net/779824/ekonomika/upravlenie_finansovymi_riskami_usloviyah_tsifrovizatsii

Avilkina, A. S. (2020). Management of financial risks of the organization in the context of digitalization. In: Transformation of economics and finance in the digital era. Proceedings of the $14^{\text {th }}$ National scientific and practical conference with international participation (pp. 43-46). Moscow, Russia: Pero Publishing House.

Bardovsky, V. P. (2019). Economics. Moscow, Russia: Forum; Infra-M, 672 p.

Bezuglaya, N. S. (2013). Economic security of the enterprise. The essence of the economic security of the enterprise. Russian Entrepreneurship, 4-1, 63-67.

Cheredanova, L. N. (2018). Fundamentals of economics and entrepreneurship. Moscow, Russia: Academia, $16 \mathrm{p}$.

Chereshkin, D. S. (2014). Risk and security management. Saint Petersburg: Lenand, 200 p.

Domashchenko, D. V. and Finogenova, Yu. Yu. (2010). Risk management in the context of financial instability. Moscow, Russia: Magister; Infra-M, 238 p

Filippova, O. (2019). Fundamentals of economics and entrepreneurship: workbook: textbook. Moscow, Russia: Academia, 288 p.

Foss, N. J. (2005). Scientific progress in strategic management: the case of the resource-based view. International Journal of Learning and Intellectual Capital, 4(1/2), 1-23.

Gomola, A. I., Kirillov, V. E. and Zhannin, P. A. (2019). Economics. Moscow, Russia: Akademia, 336 p.

Government of the Russian Federation. (2017). Order of the Government of the Russian Federation On approval of the program "Digital Economy of the Russian Federation" of 28.07.2017 No. 1632-r. Sobranie Zakonodatel'stva Rossiiskoi Federatsii [SZ RF] [Collection of Legislation of the RF] 07.08.2017, No. 32, Item 5138.

Gubanov, R. S. (2014). Insurance of financial risks as a risk management method. Financial analytics: Problems and solutions, 8, 31-35. 
Kiseleva, I. A. and Simonovich, N. E. (2014). Economic and socio-psychological security of the enterprise. National interests: Priorities and security, 5, 30-34.

Kleiner, G. B. (2014). Risks of small enterprises. Russian Economic Journal, 6, 85.

Kosov, M. E., Akhmadeev, R. G., Bykanova, O. A., Osipov, V. S., Ekimova, K. V. and Frumi, S. V. (2016). Economic practicability substantiation of financial investment choice. Journal of Applied Economic Sciences, 11 (8), 1613-1623.

Makarenko, I. A. (2020). Theory of economic analysis. Moscow, Russia: Tetra System.

Morrow, J. L., Sirmon, D. G., Hitt, M. A. and Holcomb, T. R. (2007). Creating value in the face of declining performance: firm strategies and organizational recovery. Strategic Management Journal, 8 (3), 271-283.

Nesterenko, E. A. (Ed.). (2018). Financial risk management in the digital economy: a collective monograph. Saratov, Russia: Saratov Socio-Economic Institute, The Plekhanov Russian University of Economics, $212 \mathrm{p}$.

Porter, M. (2005). Competitive advantage: how to achieve a high result and ensure its sustainability. Moscow, Russia: Alpina Business Books, 715 p.

PWC. (2019). Being a smarter risk taker through digital transformation. 2019 Risk in review study. Six characteristics for more intelligent risk management in the course of digital transformation. Retrieved from https://www.pwc.ru/ru/publications/risk-study.html

Shapkin, A. S. and Shapkin, V. A. (2013). Economic and financial risks. Assessment, management, portfolio. $9^{\text {th }}$ ed. Moscow, Russia: Dashkov and Co., $544 \mathrm{p}$.

Tereshchenko, O. N. (2019). Fundamentals of economics: a workbook. Moscow, Russia: Academia, 191 p.

Vakhitov, K. I. (2018). Economics. Textbook. Moscow, Russia: Dashkov and Co., 364 p.

Zhilkina, A. N. (2020). Financial management. Financial analysis of the enterprise: Textbook. Moscow, Russia: Infra-M. 